Magdalena Garnczarska (Kraków)

\title{
The ICONOgraphic Motif of a Griffin ANd a Hare ON THE So-CALlED SARACENIC-SiCILIAN CASKeT From the Wawel Cathedral Treasury in Cracow
}

$\mathrm{T}$

his text deals with a set of common artistic tastes connecting Islamic and Byzantine court culture. These common artistic tastes concerned the luxurious works of secular art. The main research method used to explore the issue was a comparative analysis of the iconographic sources, including the written ones. The so-called Saracenic-Sicilian casket from the Wawel Cathedral Treasury in Cracow serves as an example of the analysis of these inter-cultural connections, as it showcases the Arabic-Byzantine artistic links.

The Saracenic-Sicilian casket is made of silver and decorated in techniques such as beaten, repoussé, cast, engraved, nielloed and gilded ${ }^{1}$. It has a cuboidal form, a lid of trapezoidal sides and a rectangular handle $(18 \times 24 \times 15 \mathrm{~cm})^{2}$. The longer sides are decorated with the following combat scenes: a man killing a lion with a knife, a lion biting a naked man, an armoured horseman fighting with a footman, and a man on horseback stabbing a lion. Each scene is framed in two semi-circular arches on thickset columns. The shorter sides are decorated with fantastic animal struggles: a lion biting a creature of two bodies and one head, a dragon with two heads biting a chimera. Confronted pairs of animals are depicted on the lid: lions, griffins (on the longer sides), and peacocks. A hare-like animal ${ }^{3}$ is depicted on the top. Additionally, the base of the lid is encircled with Kufic letters. The Arabic sentence, repeated three times, is usually translated as: To you alone does the whole state

\footnotetext{
${ }^{1}$ The photographs of the casket in: A. LIC, Wybrane motywy literackie pieśni cyklu akrytyckiego w programie przedstawień na srebrnej skrzyneczce w zbiorach Muzeum Katedralnego im. Jana Pawła II na Wawelu, Kraków 2011, p. 98-101 (master's thesis; the typescript in the Institute of Art History of the Jagiellonian University in Cracow).

${ }^{2}$ M. Walczak, Casket, called a Saracenic-Sicilian casket, [in:] Wawel 1000-2000: Jubilee Exhibition. Artistic Culture of the Royal Court and the Cathedral, ed. M. PiwockA, D. Nowacki, trans. K. MaLCharek, K. Kwaśniewicz, Cracow 2000, vol. I, p. 220. The Polish version of the catalogue: Wawel 1000-2000: wystawa jubileuszowa. Kultura artystyczna dworu królewskiego i katedry, ed. M. PiwocKA, D. NowACKI, Kraków 2000, p. 219.

${ }^{3}$ It is sometimes considered as a dog, cf. A. LIC, op. cit., p. 11, 59-60.
} 
belong, and I love you, or: To the possessor of the kingdom for ever and ever ${ }^{4}$. Recently, Dorota Malarczyk of the Institute of Oriental Studies at the Jagellonian University translated it as: He is a ruler of the whole kingdom, I love you, or: The whole kingdom belongs to him, I love you ${ }^{5}$.

The casket was recorded in the 1110 inventory of the treasury of Cracow Cathedral as one of the box-shaped reliquaries. The 1563 inventory called it a reliquary for the soil sprinkled with the blood of Saint Stanislaus (gleba S. Stanislai), the bishop of Cracow, who was murdered in 1079. In 1602 the box - with other reliquaries - was put in a special container, which was hidden in the cathedral and after that it fell into oblivion. The casket was found by accident on $8^{\text {th }}$ March 1881, during the visitation by Bishop Albin Dunajewski and then it was displayed for the first time ${ }^{6}$. During the Second World War the box was in possession of Werner Kundlich (who took it on $4^{\text {th }}$ June 1940) ${ }^{7}$. The box was returned to the Wawel State Collections of Art on $23^{\text {rd }}$ July 1945 damaged, but the conservation was not carried out - by Wojciech Bochnak - until 1999. Since then it has been displayed in the John Paul II Cathedral Museum ${ }^{8}$.

For the first time the casket was analysed by Igancy Polkowski in 1881. He recognized it as Persian work from the Sassanian period of the $5^{\text {th }}$ century ${ }^{9}$. Since then, researchers have been pointing to various other possible places of origins of the box. Marian Sokołowski identified it as a Saracenic work of art from the $12^{\text {th }}$ century. Furthermore, he claimed that the casket was made in Asia, in the areas conquered by the crusaders ${ }^{10}$. Tadeusz Kruszyński suggested Sicily, because it is there, that the full fusion of the Arabic and Christian art took place in twelfth century. He also mentioned the influence of Byzantine $\operatorname{art}^{11}$. In the following years the casket was mentioned in more general publications and researchers usually just referred to the discussed hypotheses on the origin of the box ${ }^{12}$. Only recently,

\footnotetext{
${ }^{4}$ I. PolkowsKi, Skarbiec katedralny na Wawelu w 32 tablicach autografowanych przedstawiony, Kraków 1882, s.p. (cetera: skarbiec katedralny); M. Sокоєоwsкi, Trzy zabytki Dalekiego Wschodu na naszych ziemiach, SKBHS 3, 1884, p. 156. The English translation by: M. WALCZAK, op. cit., p. 220.

${ }^{5}$ English translation by the author. B. BIEdRońsKA-SŁOTA, Skrzyneczka relikwiarzowa ze skarbca katedry na Wawelu, [in:] Magistro et Amico amici discipulique. Lechowi Kalinowskiemu w osiemdziesięciolecie urodzin, ed. J. GadomsKi, Kraków 2002, p. 665.

${ }^{6}$ M. WALCZAK, op. cit., p. 219.

${ }^{7}$ For further details on this event, cf. J. URBAN, Katedra na Wawelu w latach 1939-1945 w relacji księdza Kazimierza Figlewicza, ACr 28, 1996, p. 575.

${ }^{8}$ M. WALCZAK, op. cit., p. 219.

${ }^{9}$ I. Polkowski, Dawne relikwiarze Katedry Krakowskiej, „Czas” 84, 1881, s.p.; IDEm, Skarbiec katedralny.

${ }^{10}$ M. Sокоєошsкi, op. cit., p. 153-160.

${ }^{11}$ T. Kruszyński, Srebrny relikwiarz średniowieczny w skarbcu Katedry Wawelskiej, [in:] Skarbiec Katedry Wawelskiej i Muzeum Metropolitalne, Kraków s.a., p. 8-37.

${ }^{12}$ E.g. cf.: Katalog zabytków Sztuki w Polsce, t. IV, Miasto Kraków, cz. I, Wawel, ed. J. Szablowski, Kraków 1965, s. 117-118; M. WALICKI, Wyposażenie artystyczne dworu i kościoła, [in:] Sztuka przed-
} 
Beata Biedrońska-Słotowa has put forward a new proposal about the provenance of the casket. She has discerned some links with art of the Latin West and suggested that the casket was made in France or in Germany in the second half of twelfth century ${ }^{13}$.

It should be emphasized that none of the proposed hypotheses is sufficiently convincing. Neither its iconography nor stylistic features allow for the unequivocal identification of the place of origin of the casket. Therefore, it is important to look at this situation from a different perspective, because the lack of answer to the question about the provenance is - paradoxically - also the answer. Namely, it is undeniable that the Wawel casket is an example of a high-quality and luxurious piece of art. It was probably intended for a person of high social status. Perhaps for a ruler - as it is indicated by the inscription - Islamic or Christian. In such a case, the issue of the provenience was not the most significant. Especially, as the motifs depicted on the box are universal and deeply rooted in the Mediterranean culture - combats of men and animals and fantastic creatures were well known in Arabic as well as in Christian art (both East and West, but particularly in Byzantium):

\footnotetext{
Warrior contests, battles of men and beasts, dancing, music making, and buffoonery were all favourite subjects for the courtly arts of the eastern Mediterranean, including those of Byzantium and Islam ${ }^{14}$.
}

So, all of the above-mentioned themes had the very decorative character. They can certainly be interpreted in many different ways, but it must be remembered that in secular art the references to religion were not too essential:

(...) luxury art representative of those spheres of life outside the strictly religious one, keeping in mind that in Byzantine society and culture there was never a clear-cut division between the secular and the religious. These worlds coexisted, tightly interwoven in daily life. Objects with a secular function and appearance often included religious imagery. Depictions of biblical stories on secular works did not necessarily make them religious - on the contrary, these stories were often used in the context of worldly actions and ambitions ${ }^{15}$.

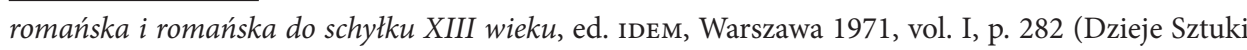
Polskiej I); G. FeHÉrvárI, Working in Metal. Mutual Influences between the Islamic World and Medieval West, JRAS 1, 1977, p. 3-16; B. MARschaK, Silberschätze des Oriens. Metallkunst des 3.-13. Jahrhunderts und ihre Kontinuität, Leipzig 1986, p. 435; M. Rożek, Wawel i Skałka. Panteony polskie, Wrocław 1995, p. 199; M. WALCZAK op. cit., p. 219-221. Detailed and recent discussion of the state of research, cf. A. LIC, op. cit., p. 14-22.

${ }^{13}$ B. Biedrońska-Słota, Skrzyneczka relikwiarzowa..., p. 675-676; cf. eadem, Orient w sztuce polskiej, [in:] Orient w sztuce polskiej, ed. EADEM, Kraków 1992, p. 23 (the box as an Arabic work); Ormianie polscy. Odrębność i asymilacja, ed. EADEM, Kraków 1999, p. 50 (with suggestion that the box was made in Cilicia).

${ }^{14}$ D. Katsarelias, Casket with Warriors and Dancers, [in:] The Glory of Byzantium. Art and Culture of the Middle Byzantine Era A.D. 843-1261, ed. H.C. Evans, W.D. Wixom, New York 1997, p. 233.

${ }^{15}$ I. Kalavrezou, Luxury Objects, [in:] ibidem, s. 219. 
What is more, the author of the casket could deliberately refrain from emphasizing any specific features pointing to a specific religion. Even the Arabic inscription does not prejudge this issue - Christian art objects were often decorated with stylized Arabic letters. In addition, Dorota Malarczyk, noted that the inscription contains a lot of mistakes, and therefore, it could not have been done by an Arab calligrapher ${ }^{16}$. It is worth mentioning that not only Christians - particularly the Syrians and the Copts, who lived perpetually under Muslim rule $^{17}$ - applied the Islamic motifs, but also Muslims included Christian imagery. A very interesting example of this phenomenon are the scenes from the life of Christ above a polo match that are situated on a basin made (circa 1247-1249) for Sultan al-Malik al-Salih Najm al-Din Ayyub ${ }^{18}$.

Caskets such as that in Cracow - and other luxurious items - were often exchanged as royal gifts ${ }^{19}$. In this context, it is worth noting the Book of Treasures and Gifts (circa 1060-1071) published in 1959 by Muhammad Hamidullah. It includes legends, but also many true stories (verified through other sources). Some of them deal with relations between Muslim and non-Muslim courts. This text is crucial, because it allows a close examination of the topic of Islamic and Byzantine court culture ${ }^{20}$. A good opportunity for the exchange of gifts was a diplomatic journey. To ensure the success of the mission, presents not only had to be expensive and elaborate, but also could not offend religious feelings of a ruler. For this reason, works of art contained secular motifs belonging to the common thematic area. For instance, both Muslims and Byzantines valued pictures based on the Alexander Romance, the legendary story of Alexander the Great attributed to Pseudo-Callisthenes ${ }^{21}$. A good example of these preferences is the richly illustrated manuscript (containing as many as 250 miniatures), stored in the Hellenic Institute of Byzantine and Post-Byzantine Studies in Venice

\footnotetext{
${ }^{16}$ B. BiedRoŃsKa-SŁota, Skrzyneczka relikwiarzowa..., p. 665.

${ }^{17}$ About the development of Christian art in the Islamic East, cf.: T.K. Thоmas, Christians in the Islamic East, [in:] The Glory of Byzantium..., p. 365-387; EADEM, The Arts of Christian Communities in the Medieval Middle East, [in:] Byzantium. Faith and Power (1261-1557), ed. H.C. Evans, New York 2004, p. 415-447.

${ }^{18}$ A. Eastmond, Beyond Byzantium, [in:] Byzantium 330-1453, ed. R. Cormack, M. Vassilaki, London 2008, p. 313-314. Cf.: Basin 1247-1249, Ayyubid period, Reign of Sultan Najmal-Din Ayyub, F1955.10, http://www.asia.si.edu/collections/zoomObject.cfm?ObjectId=10908 [30 I 2015].

${ }^{19}$ E.g., cf.: A. CutLer, Gifts and Gift Exchange as Aspects of the Byzantine, Arab, and Related Economies, DOP 55, 2001, p. 247-278; P. SouceK, Byzantium and the Islamic East, [in:] The Glory of Byzantium, p. 403-433; C.C. Connor, New Perspectives on Byzantine Ivory, Ges 30.2, 1991, p. 100-111; M. CANARD, Les relations politiques et sociales entre Byzance et les Arabes, DOP 18, 1964, p. 35-56. ${ }^{20}$ O. Grabar, The Shared Culture of Objects, [in:] Byzantine East, Latin West: Art-Historical Studies in Honor of Kurt Weitzmann, ed. D. MourIKI, Princeton 1995, p. 115-116.

${ }^{21}$ E.g., cf.: S. Gero, The Alexander Legend in Byzantium: Some Literary Gleanings, DOP 46, 1992, p. 83-87; F. Doufikar-Aerts, Sirat al-Iskandar: an Arabic Popular Romance of Alexander, OM 22.2 (83), 2003, p. 505-520.
} 
(Cod. 5), dating back to the mid to late $14^{\text {th }}$ century. The codex owner was probably Alexius III Comnenus (1349-1390) ${ }^{22}$, a Byzantine monarch living in the successor empire of Trebizond ${ }^{23}$. Some details of costumes depicted - like turbans - point to Byzantine relationship with the Islamic neighbours. They also highlight multiethnic population of Trebizond. In 1461 the book was taken over by the Turks. Then, they provided the manuscript with the inscriptions in Turkish, because the story was also very popular in the Islamic world ${ }^{24}$. Without a doubt, both cultures regarded Alexander as the ideal ruler and warrior.

After outlining one of the aspects of artistic links between Muslims and Byzantines - which, certainly, could take a different form ${ }^{25}$ - I would like to focus on the motifs of a griffin and a hare because both are depicted on the Wawel casket and, what is the most important, they are common themes in Islamic and Byzantine art.

A griffin is a legendary, hybrid creature having the body, back legs, and tail of a lion, the head (with the pointed ears), wings, and talons (as its front feet) of an eagle. It is a combination of a lion, the king of beasts, and an eagle, the ruler of the air. This fantastic animal has probably an oriental origin - it could come from the Eastern to the Greek art, Roman, and after that to the Byzantine one ${ }^{26}$. Islamic art exploited both the oriental and Byzantine sources.

Flavius Philostratus mentioned griffins in The Life of Apollonius of Tyana (III, 48; VI, 1):

As to the gold which the griffins dig up, there are rocks which are spotted with drops of gold as with sparks, which this creature can quarry because of the strength of its beak. "For these animals do exist in India," he said, "and are held in veneration as being sacred to the Sun; and the Indian artists, when they represent the Sun, yoke four of them abreast to draw the imaged car; and in size and strength they resemble lions but having this advantage over them that they have wings, they will attack them, and they get the better of elephants and

\footnotetext{
${ }^{22}$ J. Ball, The Alexander Romance, [in:] Byzantium. Faith and Power..., p. 62.

${ }^{23}$ M. DĄвrowsKa, Aleksy III Komnen, [in:] Encyklopedia kultury bizantyńskiej, ed. O. Jurewicz, Warszawa 2002, p. 19.

${ }^{24}$ J. BALL, op. cit., p. 62-63.

${ }^{25}$ E.g. about the artistic relationship between Islamic and Byzantine art, cf.: A. WALKer, The Emperor and the World: Exotic Elements and the Imaging of Middle Byzantine Imperial Power, Ninth to Thirteenth Centuries, Cambridge 2012; Byzantium and Islam: Age of Transition ( $7^{\text {th }}-9^{\text {th }}$ Century), ed. H.C. Evans, New York 2012; A. Walker, Cross-Cultural Reception in the Absence of Texts: The Islamic Appropriation of a Middle Byzantine Rosette Casket, Ges 47.2, 2008, p. 99-122; EADEM, Meaningful Mingling: Classicizing Imagery and Islamicizing Script in a Byzantine Bowl, ArtB 90, No. 1, 2008, p. 32-53; E. Dauterman Maguire, H. Maguire, Other Icons. Art and Power in Byzantine Secular Culture, Princeton 2007, p. 29-57; D. JaCOBY, Silk Economics and Cross-Cultural Artistic Interaction: Byzantium, the Muslim World, and the Christian West, DOP 58, 2004, p. 197-240; O. GraBAR, Islamic Art and Byzantium, DOP 18, 1964, p. 67-88.

${ }^{26}$ Cf.: H. Brandenburg, Greif, [in:] RAC, vol. XII, Stuttgart 1983, p. 951-995; A.M. Bisi, Il grifone. Storia di un motivo iconografico nell' antico Oriente mediterraneo, Roma 1965.
} 
of dragons. But they have no great power of flying, not more than have birds of short flight; for they are not winged as is proper with birds, but the palms of their feet are webbed with red membranes, such that they are able to revolve them, and make a flight and fight in the air; and the tiger alone is beyond their powers of attack, because in swiftness it rivals the winds"27. (...) And the griffins of the Indians and the ants of the Ethiopians, though they are dissimilar in form, yet, from what we hear, play similar parts; for in each country they are the guardians of gold, and devoted to the gold reefs of the two countries ${ }^{28}$.

Ambiguous symbolism of a griffin makes it difficult to interpret it in the respective cases, however, Christianity accepted it as a symbol of vigilance. Moreover, its body composed of two great and powerful animals was perceived to indicate the two natures of Christ: divine and human. Griffins were also regarded as extremely righteous animals, because they were faithful to one partner in lifetime ${ }^{29}$. Alexander the Great's celestial journey - carried heavenward in the chariot pulled by a pair of griffins - was associated with the Ascension of Christ ${ }^{30}$. Sometimes, however - particularly during the $11^{\text {th }}$ and $12^{\text {th }}$ centuries - griffins were interpreted as demonic animals, very vain and harmful ${ }^{31}$. Still, this was not consistent, as evidenced by the works of late Byzantine art. What is more, at that time griffins appear in sculptural decoration of churches ${ }^{32}$. They often had royal as well as religious connotations ${ }^{33}$.

In contrast, hares were considered as lunar animals and as a symbol of fertility. In early Christian art, they meant a short life of every human and also catechumens, preparing for baptism. Saint Ambrose interpreted them as a symbol of the Resurrection. These animals were regarded as quick, crafty, skittish, and watchful (according to some records, they had to sleep with open eyes) ${ }^{34}$. In the Old Testament, hares are among the unclean animals: Lepus quoque: nam et ipse ruminat, sed ungulam non dividit $(\operatorname{Lv} 11,6)^{35}$; De his autem, quae ruminant, et ungulam non findunt, comedere non debetis, ut camelum, leporem, choerogryllum:

\footnotetext{
${ }^{27}$ Flavius Philostratus, The Life of Apollonius of Tyana, III, 48, trans. F.C. Conybeare, Oxford -New York 1912 (cetera: Philostratus).

${ }^{28}$ Philostratus, VI, 1 (trans. F.C. Conybeare).

${ }^{29}$ S. Kobielus, Bestiarium chrześcijańskie. Zwierzęta w symbolice i interpretacji. Starożytność $i$ średniowiecze, Warszawa 2002, p. 109; L. RÉAU, Iconographie de l’art chrétien, Paris 1955, vol. I, p. 88.

${ }^{30}$ S. Kobielus, op. cit., p. 111. About examples in art, cf.: R.S. Loomis, Alexander the Great's Celestial Journey. I - Eastern Examples, BMag 32.181, 1918, p. 136-140.

${ }^{31}$ D. Forstner, Świat symboliki chrześcijańskiej. Leksykon, ed. et trans. W. ZaKrzewsKa, P. PACHCiareK, R. TurzyŃski, Warszawa 2001, p. 344; S. Kobielus, op. cit., p. 109.

${ }^{32}$ S. Ćurčıć, Some Uses (and Reuses) of Griffins in Late Byzantine Art, [in:] Byzantine East, Latin West, p. 597-601.

${ }_{33}^{3}$ В.П. ДАРКЕвич, Светское искусство Византии. Произведения византийского ремесла в Восточной Европе X-ХIII века, Москва 1975, p. 158; S. ĆURс̌ı́́, op. cit., p. 599-600.

${ }^{34}$ D. Forstner, op. cit., s. 309; S. Kobielus, op. cit., p. 348-349.

${ }^{35}$ Latin Vulgate (Clementine), Book Of Leviticus, 11,6, http://www.drbo.org/lvb/chapter/03011.htm

[30 I 2015] (cetera: Latin Vulgate).
} 
haec, quia ruminant et non dividunt ungulam, immunda erunt vobis (Dt 14,7$)^{36}$. Their extraordinary ability to reproduce led them to being considered as lewd and lustful animals. Because of this, hares tend to be seen as an attribute of Luxury or Voluptuousness ${ }^{37}$. It should not be omitted that these small animals were rich in multifarious and ambivalent symbolism.

On the other hand, hares were a common decorative motif. Hunting for them was one of the court entertainments (their meat was a highly valued delicacy) - then, courtiers could demonstrate their hunting skills and quickness ${ }^{38}$. That is why hares are so popular in works of art depicting chases - of course, in the specific context these scenes could be pointed to the struggle between good and evil. Furthermore, they also served - in Islamic, as well as in Byzantine art - as a single motif, or accompanied other animals, or humans, or deities, or ornaments ${ }^{39}$.

Having delineated only briefly the possible meanings of both animals, it is worthwhile to present a few examples of works of Islamic and Byzantine art. In the first place, they will be associated with secular art (or of unknown context):

A key iconographic source for such images is encountered in Sasanian art, especially in the decoration of metalwork with reference to royal power. Hunting scenes with or without human figures are incorporated into the iconography of the princely life ${ }^{40}$.

We can point to many examples of Byzantine ivory works containing the griffin theme. They allow us a very interesting glimpse into nonreligious art of the Byzantines. It was very popular. The excellent example is the so-called Darmstadt casket from the first half of the $10^{\text {th }}$ century (Hessisches Landesmuseum, Darmstadt, Germany). At the one of the end panels there is one of the earliest representations of Alexander the Great celestial journey. He is depicted with the insignia of a Byzantine emperor, sitting in a chariot pulled by a pair of griffins ${ }^{41}$. Another example is the casket in the Petit Palais Museum in Paris $\left(10^{\text {th }}-11^{\text {th }}\right.$ century). The lid is decorated with the images of griffins in various poses. They are full of refined charm ${ }^{42}$. The marble reliefs have also a very decorative character; for instance the splendid panel in The Metropolitan Museum of Art in New York

${ }^{36}$ Latin Vulgate, Book Of Deuteronomy, 14,7, http://www.drbo.org/lvb/chapter/05014.htm [30 I 2015].

${ }^{37}$ S. Kobielus, op. cit., p. 350.

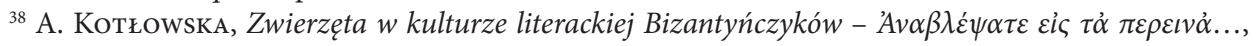
Poznań 2013 (Seria Historia 224), p. 42-43.

${ }^{39}$ M. Moraitou, Animal Motifs, [in:] Byzantium and Islam..., p. 172.

${ }^{40}$ Ibidem.

${ }^{41}$ M. Georgopoulos, Side of a Casket with Mythological Scenes, [in:] The Glory of Byzantium..., p. 227-228.

42 J. Durand, Coffret, [in:] Byzance. L'art byzantin dans les collections publiques françaises; ed. M.O. Germain et al., Paris 1992, p. 262-263. 
(ca. 1250-1300). They show the creature contained in a medallion, with its head turned and its wings flexed ${ }^{43}$.

Griffin is also present on some preserved textiles, which may be telling, as in both cultures precious fabrics ${ }^{44}$ were of special status. One of the most noted example is the textile fragment from the reliquary of Saint Siviard $\left(11^{\text {th }}-12^{\text {th }}\right.$ century; Trésor de la Cathédrale de Saint-Étienne, Sens, France). The fabric is decorated with a profile image of a majestic griffin, and in the background there are stylized trees. This piece of art was made in the lampas technique (invented in the $11^{\text {th }}$ century), which emphasizes the contrast between the textures and the motif ${ }^{45}$. Less famous, but noteworthy, is the $10^{\text {th }}$ century Byzantine silk from Antioch. Here the silk griffins flank the eight-pointed, central star in four corner compartments. What is fascinating, the technique used in this work was rare in Byzantium and indicates Islamic links - probably, the fabric was created in Antioch under Muslim reign ${ }^{46}$.

Numerous Islamic textiles have also survived to our times. A good example of those group is the fabric fragment from al-Fustat (Cairo) in Egypt (mid-11 ${ }^{\text {th }}$ century; The Metropolitan Museum of Art, New York) - showing, in ovoid cartouches, stepping griffins. It is an ikkat textile, and this weaving technique is characteristic for Yemen; however, it also appeared in Egypt during the Fatimid period $(909-1171)^{47}$. The New York collection contains other Muslim fabrics with stylized and sumptuous griffins, including a fine fragment from the chapel of Saint Liberata from Sigüenza cathedral (first half $12^{\text {th }}$ century) $)^{48}$, the Spanish fragment $\left(13^{\text {th }}\right.$ century) depicting confronted creatures - griffins, quadrupeds, and doubleheaded eagles ${ }^{49}$, the fragment from Syria ( $13^{\text {th }}$ century) with griffins, foxes and birds situated amid plants ${ }^{50}$.

Of the other, non-textile items, that should be also noted here, one should mention a copper bowl (mid-12 $2^{\text {th }}$ century; Tiroler Landesmuseum Ferdinandeum, Innsbruck) decorated with enamel, which is a very elaborated Muslim work of art. This object contains a central medallion showing the Ascension of Alexander the Great. Griffins not only pull the chariot, but also - in the side roundels - attack quadrupeds. But, interestingly, Thomas Steppan discerned some links with

\footnotetext{
${ }^{43}$ S.T. Brooks, Relief Depicting a Griffin, [in:] Byzantium. Faith and Power, p. 112-113.

${ }^{44}$ Cf.: A. Muthesius, Byzantine Silk Weaving. AD 400 to AD 1200, Vienna 1997.

${ }^{45}$ A. Gonosová, Textile Fragment from the Reliquary of Saint Siviard, [in:] The Glory of Byzantium, p. 226.

${ }^{46}$ G. Underhill, A Tenth-Century Byzantine Silk from Antioch, BCMA 29.1, 1942, p. 6-7.

${ }^{47}$ Textile Fragment, mid-1 $1^{\text {th }}$ century, Egypt, Fustat, http://www.metmuseum.org/collection/the-collection-online/search/448072?rpp=30\&pg=1\&ft=griffin\&deptids=14\&pos=6 [30 I 2015].

${ }^{48}$ Textile Fragment from the Shrine of San Librada, Sigüenza Cathedral, http://www.metmuseum. $\mathrm{org} /$ collection/the-collection-online/search/451472? rpp=30\&pg=1\&ft=griffin\&deptids=14\&pos=12 [30 I 2015].

${ }^{49}$ Fragment, $13^{\text {th }}$ century, Spain, http://www.metmuseum.org/collection/the-collection-online/search /450535? rpp=30\&pg $=1 \& \mathrm{ft}=$ griffin\&deptids $=14 \& p o s=11$ [30 I 2015].

${ }^{50}$ Textile Fragment, $13^{\text {th }}$ century, Syria, http://www.metmuseum.org/collection/the-collection-online /search/450741? rpp=30\&pg=1\&ft=griffin\&deptids=14\&pos=10 [30 I 2015].
} 
Constantinople and suggested that the vessel may have been a Byzantine royal gift to Rukh al-Dawla Abu Sulayman Da'ud, an Artukid ruler. A debate over its provenance is still ongoing ${ }^{51}$. Another interesting example of Artukid art is a steel mirror (with gold inlay) showing a hunt on horseback (first half of $13^{\text {th }}$ century; Topkapı Sarayi Müzesi, Istanbul). The back of the mirror is also decorated - with the central field surrounded by fantastic creatures, including griffins $s^{52}$.

Sources indicate that the imperial robes were sometimes decorated with a griffin motif, because these animals were highlighting the splendour of the royal authority ${ }^{53}$. This information is confirmed by the miniature in the $13^{\text {th }}$ century Byzantine chronicle. The miniature shows the emperor wearing the attire with griffins in roundels ${ }^{54}$.

Hares were also popular, however, their images were more frequent in the less luxurious works of art. This observation is exemplified by: the floor (or cushion) wool fragment with running hares $\left(4^{\text {th }} / 5^{\text {th }}\right.$ century; The Walters Art Museum, Baltimore) ${ }^{55}$; the wool band (probably it was a part of a tunic) with the profile of a black hare crouching on a bed of leaves $\left(5^{\text {th }} / 7^{\text {th }}\right.$ century; The Metropolitan Museum of Art, New York) ${ }^{56}$, the fragment of Coptic neck band from a tunic, which contains playing erotes, fish, hares, and lions among stylized flora ${ }^{57}\left(5^{\text {th }} / 8^{\text {th }}\right.$ century; The Metropolitan Museum of Art, New York).

Besides, there are more sumptuous pieces of art with hares, such as: the ivory comb in the Hermitage, which is decorated with carving. On one side there is an image of a jumping hare $\left(11^{\text {th }} \text { century }\right)^{58}$, the bowl with three animals (1100-1300; The Metropolitan Museum of Art, New York) - a panther, deer, and a hare - evoked the hunt ${ }^{59}$. It was a very popular theme in the $12^{\text {th }}-$ and $13^{\text {th }}$-century Byzantine ceramics ${ }^{60}$. The most splendid item is a group of Byzantine silver bowls now preserved in the Hermitage Museum in St. Petersburg (12 ${ }^{\text {th }}$ century). These elaborated vessels are decorated with the court scenes, including the hunt.

\footnotetext{
${ }^{51}$ P. Soucek, Bowl with the Ascension of Alexander, [in:] The Glory of Byzantium, p. 422-423.

${ }^{52}$ EADEM, Mirror with a Hunter on Horseback, [in:] The Glory of Byzantium, p. 424.

${ }^{53}$ S. ĆURČIĆ, op. cit., p. 599-600.

${ }^{54}$ В.П. ДАРКЕВИЧ, op. cit., p. 194.

${ }^{55}$ Floor or Cushion Cover Fragment with Running Hares, http://art.thewalters.org/detail/9328/flooror-cushion-cover-fragment-with-running-hares/ [30 I 2015].

${ }^{56}$ M. Moraitou, op. cit., p. 172-173.

${ }^{57}$ Neck Band from a Tunic, $5^{\text {th }}-8^{\text {th }}$ century, Egypt, http://www.metmuseum.org/collection/the-collection-online/search $/ 444064$ ? rpp=90\&pg=2\&ao=on\&ft=hare\&pos=105 [30 I 2015].

${ }^{58}$ A. BAnk, Byzantine Art in the Collections of Soviet Museums, Leningrad 1985, p. 295.

${ }^{59}$ Bowl with Three Animals, 1100-1300, Byzantine, http://www.metmuseum.org/collection/the-collection-online/search/465952? $\mathrm{rpp}=90 \& \mathrm{pg}=2 \& \mathrm{ft}=\mathrm{hare} \& \mathrm{pos}=136$ [30 I 2015]. Cf.: E. DAUTERMAN Maguire, Dish with Garden Animals, [in:] The Glory of Byzantium, p. 268; EAdem, Plate with Lovers in a Garden, [in:] ibidem, p. 270-271.

${ }^{60}$ В.П. ДАРКевич, op. cit., p. 78-99; E. Dauterman Maguire, H. Maguire, op. cit., p. 49-53.
} 
For instance, on the rim of the bowl from Beryozovo there is an image of a dog chasing a hare ${ }^{61}$.

Examples of Islamic works of art with hares - were generally regarded as a symbol of prosperity and fertility ${ }^{62}$ - are also noteworthy. One of those is the flask with emerald-green cameo decoration, presumably originating from Iran $\left(9^{\text {th }}-10^{\text {th }}\right.$ century; The British Museum, London). The stylised hare is applied to the surface of the spherical body of the long-necked bottle ${ }^{63}$. In another example, the ceramic bowl from the Benaki Museum in Athens $\left(9^{\text {th }}-10^{\text {th }}\right.$ century), hares form a radiating design. The ornamental treatment of motifs was standard in the $9^{\text {th }}$-century Abbasid Iraq $q^{64}$. Extraordinarily charming image of a hare is depicted on the bowl from Egypt (first quarter of the $11^{\text {th }}$ century; The Metropolitan Museum of Art, New York). The animal is depicted running with a spray of leaves in its mouth ${ }^{65}$. A similar freshness characterises the hare from the islamic bestiary $\left(11^{\text {th }}-12^{\text {th }}\right.$ century; The Metropolitan Museum of Art, New York). It is very realistic image. The brass tray (with silver inlay) in the Hermitage (ca. 1240-1250) is also worth mentioning. This object is an Ayyubid product. The round tray is encircled with band, which comprises stylised representations of running animals - among them there are hares ${ }^{66}$.

To conclude, the mentioned Byzantine and Islamic works of art depicting griffins and hares, visibly affirm the hypothesis that in Late Antiquity and Middle Ages a set of common aesthetic and iconographic preferences existed among the elites of Christians and Muslims, even if understanding of the motives was different in detail. The courts of both cultures prized luxurious and exquisite items, particularly those made of ivory, silk, and precious metals, because these costly objects emphasized the prestige of their owners. What is more, in those works religious issues were marginalized - themes usually originated from Antiquity, were well established in the Mediterranean culture, and, what is most significant, were associated with certain values, appreciated at the royal courts. Besides, those themes also had a decorative value. Furthermore, some themes - such as griffins and hares - were also common in less sophisticated works. In my view it is fair to conclude that the so-called Saracenic-Sicilian casket is a typical example of a highquality piece of courtly art, which exemplifies intricate relationship between Islamic and Byzantine art.

${ }^{61}$ E. Dauterman Maguire, H. Maguire, op. cit, p. 47-49.

${ }^{62}$ M. Moraitou, Figurine of a Crouching Hare, [in:] Byzantium and Islam, p. 174.

${ }^{63}$ EAdem, Flask with Green Cameo Decoration, [in:] ibidem, p. 173.

${ }^{64}$ EADEM, Luster-Painted Bowl, [in:] ibidem, p. 174.

${ }^{65}$ Bowl Depicting a Running Hare, Egypt, Islamic, http://www.metmuseum.org/collection/the-collection-online $/$ search $/ 451769$ ? rpp $=90 \& p g=1 \& \mathrm{ft}=$ hare\&deptids $=14 \& p o s=2$ [30 I 2015].

${ }^{66}$ S. CARboni, Tray, [in:] Byzantium and Islam, p. 424-425. 


\section{Bibliography}

\section{Sources}

Flavius Philostratus, The Life of Apollonius of Tyana, trans. F.C. Conybeare, Oxford-New York 1912. Latin Vulgate (Clementine), http://www.drbo.org/lvb/chapter/03011.htm.

\section{Secondary literature}

Ball J., The Alexander Romance, [in:] Byzantium. Faith and Power (1261-1557), ed. H.C. Evans, New York 2004.

Bank A., Byzantine Art in the Collections of Soviet Museums, Leningrad 1985.

Basin 1247-1249, Ayyubid period, Reign of Sultan Najmal-Din Ayyub, F1955.10, http://www.asia.si. edu/collections/zoomObject.cfm?ObjectId $=10908$

BiedrońsKa-SŁota B., Skrzyneczka relikwiarzowa ze skarbca katedry na Wawelu, [in:] Magistro et Amico amici discipulique. Lechowi Kalinowskiemu w osiemdziesięciolecie urodzin, ed. J. GadomSKI, Kraków 2002, p. 655-676.

Bisi A.M., Il grifone. Storia di un motivo iconografico nell'antico Oriente mediterraneo, Roma 1965.

Bowl Depicting a Running Hare, Egypt, Islamic, http://www.metmuseum.org/collection/the-collection -online $/$ search $/ 451769$ ? rpp=90\&pg $=1 \& \mathrm{ft}=$ hare \&deptids $=14 \&$ pos $=2$.

Bowl with Three Animals, 1100-1300, Byzantine, http://www.metmuseum.org/collection/the-collection -online $/$ search $/ 465952$ ? $\mathrm{pp}=90 \& \mathrm{pg}=2 \& \mathrm{ft}=$ hare\&pos $=136$.

Brandenburg H., Greif, [in:] RAC, vol. XII, Stuttgart 1983, p. 951-995.

Brooks S.T., Relief Depicting a Griffin, [in:] Byzantium. Faith and Power(1261-1557), ed. H.C. Evans, New York 2004, p. 112-113.

Byzantium and Islam: Age of Transition ( $7^{\text {th }}-9^{\text {th }}$ Century), ed. H.C. Evans, New York 2012.

CANARD M., Les relations politiques et sociales entre Byzance et les Arabes, DOP 18, 1964, p. 35-56.

Connor C.C., New Perspectives on Byzantine Ivory, Ges 30.2, 1991, p. 100-111.

Ćurčıć S., Some Uses (and Reuses) of Griffins in Late Byzantine Art, [in:] Byzantine East, Latin West, p. 597-604.

Cutler A., Gifts and Gift Exchange as Aspects of the Byzantine, Arab, and Related Economies, DOP 55,2001 , p. 247-278.

Даркевич В.П., Светское искусство Византии. Произведения византийского ремесла в Восточной Европе X-ХІІІ века, Москва 1975.

Dauterman Maguire E., Dish with Garden Animals, [in:] The Glory of Byzantium. Art and Culture of the Middle Byzantine Era A.D. 843-1261, ed. H.C. Evans, W.D. Wixom, New York 1997, p. 268.

Dauterman Maguire E., Plate with Lovers in a Garden, [in:] The Glory of Byzantium. Art and Culture of the Middle Byzantine Era A.D. 843-1261, ed. H.C. Evans, W.D. Wixom, New York 1997, p. 270-271.

Dauterman Maguire E., Maguire H., Other Icons. Art and Power in Byzantine Secular Culture, Princeton 2007.

Doufikar-Aerts F., Sìrat al-Iskandar: an Arabic Popular Romance of Alexander, OM 22.2 (83), 2003, p. 505-520. 
Durand J., Coffret, [in:] Byzance. L'art byzantin dans les collections publiques françaises; ed. M.O. Germain et al., Paris 1992, p. 262-263.

Eastmond A., Beyond Byzantium, [in:] Byzantium 330-1453, ed. R. CoRmack, M. Vassilaki, London 2008, p. 307-314.

Encyklopedia kultury bizantyńskiej, ed. O. JuREwicz, Warszawa 2002.

Fehérvári G., Working in Metal. Mutual Influences between the Islamic World and Medieval West, JRAS 1, 1977, p. 3-16.

Floor or Cushion Cover Fragment with Running Hares, http://art.thewalters.org/detail/9328/floor-or -cushion-cover-fragment-with-running-hares/.

Forstner D., Świat symboliki chrześcijańskiej. Leksykon, ed. et trans. W. ZaKrzewska, P. PachciaREK, R. TURZYŃsKi, Warszawa 2001.

Fragment, $13^{\text {th }}$ century, Spain, http://www.metmuseum.org/collection/the-collection-online/search /450535?rpp=30\&pg=1\&ft=griffin\&deptids=14\&pos=11.

Georgopoulos M., Side of a Casket with Mythological Scenes, [in:] The Glory of Byzantium. Art and Culture of the Middle Byzantine Era A.D. 843-1261, ed. H.C. Evans, W.D. Wixom, New York 1997, p. 227-228.

Gero S., The Alexander Legend in Byzantium: Some Literary Gleanings, DOP 46, 1992, p. 83-87.

Gonosoví A., Textile Fragment from the Reliquary of Saint Siviard, [in:] The Glory of Byzantium. Art and Culture of the Middle Byzantine Era A.D. 843-1261, ed. H.C. Evans, W.D. Wixom, New York 1997, p. 226.

Grabar O., Islamic Art and Byzantium, DOP 18, 1964, p. 67-88.

Grabar O., The Shared Culture of Objects, [in:] Byzantine East, Latin West: Art-Historical Studies in Honor of Kurt Weitzmann, ed. D. Mouriki, Princeton 1995, p. 115-129.

JАСов D., Silk Economics and Cross-Cultural Artistic Interaction: Byzantium, the Muslim World, and the Christian West, DOP 58, 2004, p. 197-240.

Kalavrezou I., Luxury Objects, [in:] The Glory of Byzantium. Art and Culture of the Middle Byzantine Era A.D. 843-1261, ed. H.C. Evans, W.D. Wixom, New York 1997, p. 219-253.

Katalog zabytków Sztuki w Polsce, t. IV, Miasto Kraków, cz. I, Wawel, ed. J. Szablowski, Kraków 1965.

Katsarelias D.G., Casket with Warriors and Dancers, [in:] The Glory of Byzantium. Art and Culture of the Middle Byzantine Era A.D. 843-1261, ed. H.C. Evans, W.D. Wixom, New York 1997, p. 233.

Kobielus S., Bestiarium chrześcijańskie. Zwierzęta w symbolice i interpretacji. Starożytność i średniowiecze, Warszawa 2002.

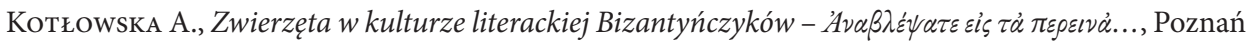
2013 (Seria Historia 224).

KRUSZYŃsKi T., Srebrny relikwiarz średniowieczny w skarbcu Katedry Wawelskiej, [in:] Skarbiec Katedry Wawelskiej i Muzeum Metropolitalne, Kraków s.a., p. 8-37.

LIC A., Wybrane motywy literackie pieśni cyklu akrytyckiego w programie przedstawień na srebrnej skrzyneczce w zbiorach Muzeum Katedralnego im. Jana Pawła II na Wawelu, Kraków 2011 [MA thesis].

Loomis R.S., Alexander the Great's Celestial Journey. I - Eastern Examples, Bmag 32, No. 181, 1918, p. $136-140$. 
Marschaк B., Silberschätze des Oriens. Metallkunst des 3.-13. Jahrhunderts und ihre Kontinuität, Leipzig 1986.

Muthesius A., Byzantine Silk Weaving. AD 400 to AD 1200, Vienna 1997.

Neck Band from a Tunic, $5^{\text {th }}-8^{\text {th }}$ century, Egypt, http://www.metmuseum.org/collection/the-collection -online/search $/ 444064$ ?rpp=90\&pg=2\&ao=on \&ft=hare\&pos=105.

Orient w sztuce polskiej, ed. B. BiedrońsKa-SŁOta, Kraków 1992.

Polkowski I., Dawne relikwiarze Katedry Krakowskiej, „Czas” 84, 1881, s.p.

Pоцкошsкi I., Skarbiec katedralny na wawelu w 32 tablicach autografowanych przedstawiony, Kraków 1882.

RÉAU L., Iconographie de l’art chrétien, Paris 1955.

Rożex M., Wawel i Skałka. Panteony polskie, Wrocław 1995.

SoкоŁowsкi M., Trzy zabytki Dalekiego Wschodu na naszych ziemiach, SKBHS 3, 1884, p. 141-162.

SouceK P., Byzantium and the Islamic East, [in:] The Glory of Byzantium. Art and Culture of the Middle Byzantine Era A.D. 843-1261, ed. H.C. Evans, W.D. Wixom, New York 1997, p. 403-433.

Sztuka przedromańska i romańska do schyłku XIII wieku, ed. M. WALICKI, Warszawa 1971.

Textile Fragment, mid-11 ${ }^{\text {th }}$ century, Egypt, Fustat, http://www.metmuseum.org/collection/thecollection-online/ search $/ 448072$ ? $\mathrm{rpp}=30 \& \mathrm{pg}=1 \& \mathrm{ft}=$ griffin\&deptids $=14 \& \mathrm{pos}=6$.

Textile Fragment from the Shrine of San Librada, Sigüenza Cathedral, http://www.metmuseum. org/collection/the-collection-online/ search $/ 451472$ ? rpp=30\&pg=1\&ft=griffin\&deptids $=14 \&$ pos $=12$.

Textile Fragment, $13^{\text {th }}$ century, Syria, http://www.metmuseum.org/collection/the-collection-online $/$ search $/ 450741$ ?rpp=30\&pg=1\&ft=griffin\&deptids $=14 \& p o s=10$.

Thomas T.K., The Arts of Christian Communities in the Medieval Middle East, [in:] Byzantium. Faith and Power (1261-1557), ed. H.C. Evans, New York 2004, p. 415-426.

Thomas T.K., Christians in the Islamic East, [in:] The Glory of Byzantium. Art and Culture of the Middle Byzantine Era A.D. 843-1261, ed. H.C. Evans, W.D. Wixom, New York 1997, p. 365-387.

Underhill G., A Tenth-Century Byzantine Silk from Antioch, BCMA 29.1, 1942, p. 6-7.

Urban J., Katedra na Wawelu w latach 1939-1945 w relacji księdza Kazimierza Figlewicza, ACr 28, 1996, p. 569-580.

Walczá M., Casket, called a Saracenic-Sicilian casket, [in:] Wawel 1000-2000: Jubilee Exhibition. Atistic Culture of the Royal Court and the Cathedral, ed. M. Piwocka, D. Nowacki, trans. K. MalchareK, K. Kwaśniewicz, Cracow 2000, p. 219-221.

Walker A., Cross-Cultural Reception in the Absence of Texts: The Islamic Appropriation of a Middle Byzantine Rosette Casket, Ges 47.2, 2008, p. 99-122.

Walker A., The Emperor and the World: Exotic Elements and the Imaging of Middle Byzantine Imperial Power, Ninth to Thirteenth Centuries, Cambridge 2012.

Walker A., Meaningful Mingling: Classicizing Imagery and Islamicizing Script in a Byzantine Bowl, ArtB 90.1, 2008, p. 32-53.

Wawel 1000-2000: wystawa jubileuszowa. Kultura artystyczna dworu królewskiego i katedry, ed. M. Piwocka D. Nowacki, Kraków 2000. 


\begin{abstract}
The article examines a kind of community of aesthetic tastes that was connecting Arab and Byzantine courtly culture. This community concerned the secular and luxurious works of art. The silver casket, called a Saracenic-Sicilian, from the Wawel Cathedral Treasury in Cracow will serve as the starting point to gain a true appreciation of the complex artistic relationship between the Byzantine Empire and the Islamic world in the Middle Ages. It appears highly probable that the casket was created in the twelfth century. It was published at once after the discovery ( $8^{\text {th }}$ March 1881) and since then, researchers argue about the place of origin of the box. Some suggest that the casket could be a product of Arabic or Persian art, while others propose either Byzantine or Sicilian workshops. What is more, even an thorough stylistic and iconographic analysis does not allow for an unambiguous resolution of the problem of provenance of the Wawel box. Lack of a resolution suggests that this piece of art was directed to a member of the cosmopolitan elite of - Arabic or Byzantine - court, which took delight in sophisticated and expensive luxury items. It is worth noting that in this case, matter of religion did not play a crucial role. For this reason, the depicted scenes and decorative details have an universal character. In order to present this specific synthesis of Arabic and Byzantine secular art, the motifs of a griffin and a hare, decorating the casket will be considered.
\end{abstract}

Keywords: griffin, hare, Islamic, Byzantine, casket

\title{
Magdalena Garnczarska
}

Uniwersytet Jagielloński

Instytut Historii Sztuki

magdalena.garnczarska@gmail.com

ul. Por. Halszki 37/58

Kraków 30-611, Polska/Poland magdalena.garnczarska@gmail.com 